JURNAL ILMIAH MANAJEMEN BISNIS DAN INOVASI UNIVERSITAS SAM RATULANGI (JMBI UNSRAT)

\title{
DETERMINAN PERTUMBUHAN EKONOMI DAN DAMPAKNYA TERHADAP TINGKAT PENYERAPAN TENAGA KERJA SERTA KEMISKINAN DI KABUPATEN KEPULAUAN SANGIHE DAN KABUPATEN KEPULAUAN SITARO
}

Robby J. Kumaat

Universitas Sam Ratulangi

A R T I C L E I N F O

\begin{tabular}{lc}
\hline Kata Kunci: & Determinan \\
Pertumbuhan & Ekonomi, \\
Penyerapan Tenaga & Kerja dan \\
Kemiskinan &
\end{tabular}

Corresponding author:

Robby J. Kumaat

kumaatrjoan@unsrat.ac.id

\begin{abstract}
Abstrak: Salah satu sasaran pembangunan nasional adalah menurunkan tingkat kemiskinan dan penyerapan tenaga kerja untuk itu pelaksanaan pembangunan diharapkan dapat seimbang jangan ada kesejangan antar daerah yang tidak meratanya perhatian pemerintah ketiap-tiap daerah. Negara Indonesia bertujuan untuk memajukan dan meningkat kesejahteraan rakyat, oleh karena itu, upaya pengentasan kemiskinan harus dilakukan secara komprehensif, mencakup berbagai aspek kehidupan dan dilaksanakan secara berkesinambungan. Perencanaan merupakan sebuah upaya untuk mengantisipasi ketidakseimbangan yang terjadi yang bersifat akumulatif, artinya, perubahan yang terjadi pada sebuah keseimbangan awal dapat menyebabkan perubahan pada sistem sosial yang kemudian akan membawa sistem yang ada menjauhi keseimbangan semula. Tujuan penelitian ini adalah untuk melihat bagaimana pengaruh determinan pertumbuhan ekonomi dan dampaknya terhadap penyerapan tenaga kerja serta kemiskinan. Metode penelitian yang digunakan adalah analisis jalur. Hasil penelitian di Kabupaten Kepulauan Sangihe menunjukan bahwa belanja langsung berpengaruh positif terhadap pertumbuhan ekonomi sedangkan di Kabupaten Kepulauan Siau Tagulandang Biaro belanja langsung berpengaruh negatif terhadap pertumbuhan ekonomi. Hasil penelitian di Kabupaten Kepulauan sangihe menunjukan bahwa belanja langsung berpengaruh positif terhadap penyerapatan tenaga kerja dan pertumbuhan ekonomi berpengaruh negatif terhadap penyerapan tenaga kerja. Sedangkan di Kabupaten Kepulauan Siau Tagulandang Biaro belanja langsung berpengaruh positif terhadap penyerapan tenaga kerja dan pertumbuhan ekonomi berpengaruh negative terhadap penyerapan tenaga kerja. Hasil penelitian di Kabupaten Kepulauan Sangihe menunjukan bahwa belanja langsung berpengaruh negatif terhadap kemiskinan dan pertumbuhan ekonomi berpengaruh positif terhadap kemiskinan. Sedangkan di Kabupaten Kepulauan Siau Tagulandang Biaro belanja langsung dan pertumbuhan ekonomi berpengaruh negatif terhadap kemiskinan.
\end{abstract}




\section{Pendahuluan}

\section{Latar Belakang}

Pembangunan daerah merupakan bagian integral dari pembangunan nasional. Pembangunan yang dilaksanakan diharapkan dapat meningkatkan kesejahteraan masyarakat. Salah satu tujuan pembangunan nasional adalah meningkatkan kinerja perekonomian agar mampu menciptakan lapangan kerja dan menata kehidupan yang layak bagi seluruh rakyat yang pada gilirannya akan mewujudkan kesejahteraan masyarakat. Pelaksanaan pembangunan dan pemerataan perekonomian daerah harus didukung oleh sumbersumber keuangan sendiri yang cukup, hal ini untuk menghindari ketergantungan daerah pada pemerintah pusat atau daerah tingkat atasnya. Salah satu indikator untuk mengukur keberhasilan pembangunan dalam suatu Negara adalah pertumbuhan ekonomi.

Salah satu sasaran pembangunan nasional adalah menurunkan tingkat kemiskinan dan penyerapan tenaga kerja untuk itu pelaksanaan pembangunan diharapkan dapat seimbang jangan ada kesejangan antar daerah yang tidak meratanya perhatian pemerintah ketiap-tiap daerah. Negara Indonesia bertujuan untuk memajukan dan meningkat kesejahteraan rakyat, oleh karena itu, upaya pengentasan kemiskinan harus dilakukan secara komprehensif, mencakup berbagai aspek kehidupan dan dilaksanakan secara berkesinambungan. Perencanaan merupakan sebuah upaya untuk mengantisipasi ketidakseimbangan yang terjadi yang bersifat akumulatif, artinya, perubahan yang terjadi pada sebuah keseimbangan awal dapat menyebabkan perubahan pada sistem sosial yang kemudian akan membawa sistem yang ada menjauhi keseimbangan semula.

Pertumbuhan ekonomi merupakan tolok ukur perekonomian suatu daerah. Pertumbuhan ekonomi yang tinggi dan berkelanjutan merupakan kondisi utama atau suatu keharusan bagi kelangsungan pembangunan ekonomi dan peningkatan kesejahteraan. Pada pembangunan ekonomi di daerah, tujuan pembangunan itu sendiri tidak jauh berbeda dengan tujuan pembangunan nasional. Akan tetapi, proses pembangunan di daerah jauh lebih spesifik (Tambunan, 2001). Berikut ini adalah data pertumbuhan ekonomi yang ada di Provinsi Sulawesi Utara.

\section{Grafik 1. Pertumbuhan Ekonomi Kabupaten/Kota di Provinsi Sulawesi Utara Tahun 2018}

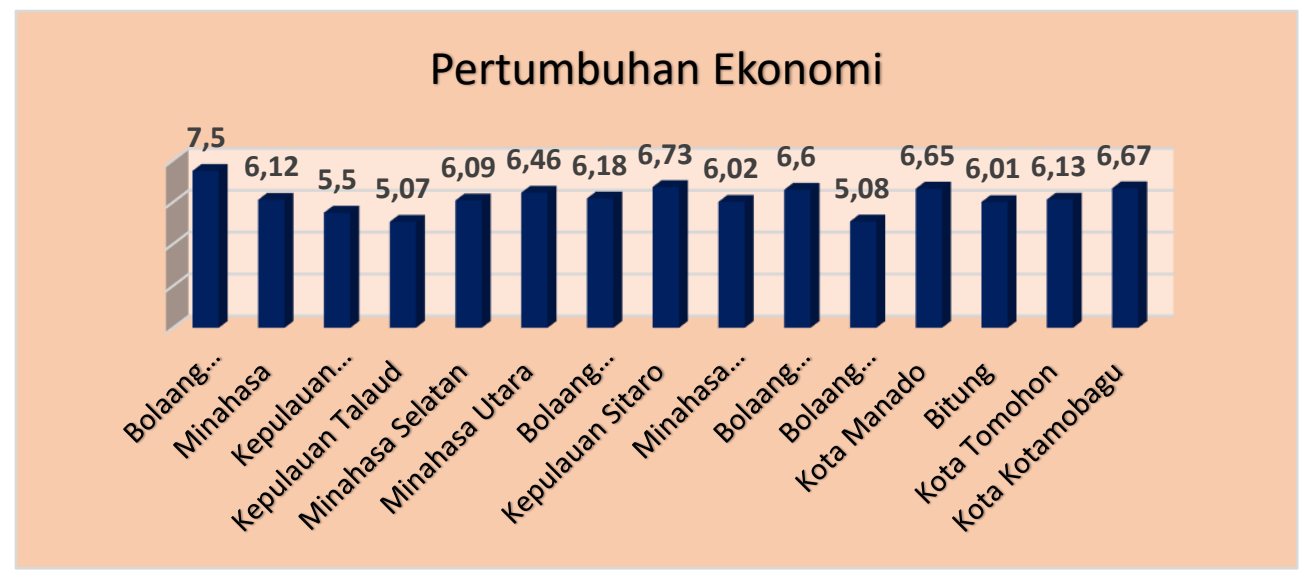

Sumber Data: BPS Sulut

Dari grafik diatas dapat dilihat bahwa pertumbuuhan ekonomi di kabupaten/kota yang ada di Provinsi Sulawesi Utara untuk tahun 2018 daerah yang tingkat pertumbuhan ekonomi terendah yaitu Kabupaten Kepulauan Talaud dengan presentase sebesar 5,07 persen kemudian yang paling tinggi ialah 
Kabupaten bolaang Mongondow sebesar 7,50 persen. Sedangkan, Kabupaten Kepulauan Sangihe berada di posisi ketiga teredah tingkat pertumbuhan ekonomi yaitu sebesar 5,50 persen dan kedua tertinggi tingkat pertumbuhan ekonomi yaitu Kabupaten Kepulaun Sitaro sebesar 6.73 persen. Peran pemerintah dalam mendorong peningkatan pertumbuhan ekonomi sangat penting, pertumbuhan ekonomi yang baik memberikan kesempatan yang lebih besar kepada daerah atau pemerintah untuk memenuhi kehidupan dasar masyarakat. Tetapi sejauh mana kebutuhan ini dipenuhi tergantung pada kemampuan suatu daerah atau pemerintah dalam mengalokasikan sumber-sumber ekonomidi antara masyarakat dan distribusi pendapatan serta kesempatan untuk memperoleh pekerjaan.

Dalam pembangunan ekonomi suatu daerah Kemiskinan merupakan salah satu masalah yang harus diselesaikan oleh pemerintah. Permasalahan kemiskinan memang merupakan masalah yang kompleks dan bersifat multidimensional. Oleh karena itu, upaya pengentasan kemiskinan harus dilakukan secara komprehensif, mencakup berbagai aspek kehidupan masyarakat, dan dilaksanakan secara terpadu (Nasir, 2008). Kemiskinan disebabkan oleh berbagai faktor, yaitu tingkat investasi yang masih dibawah standar, tingkat pengangguran yang tinggi, dan pertumbuhan ekonomi yang lambat. Kesenjangan antara masyarakat kaya dan masyarakat miskin di Indonesia semakin melebar disebabkan karena tingginya disparitas antar daerah akibat tidak meratanya distribusi pendapatan yang menjadi salah satu akar permasalahan kemiskinan di Indonesia (Sianturi, 2011).

\section{Grafik 2. Persentase Kemiskinan Kabupaten/Kota di Provinsi Sulawesi Utara Tahun 2018}

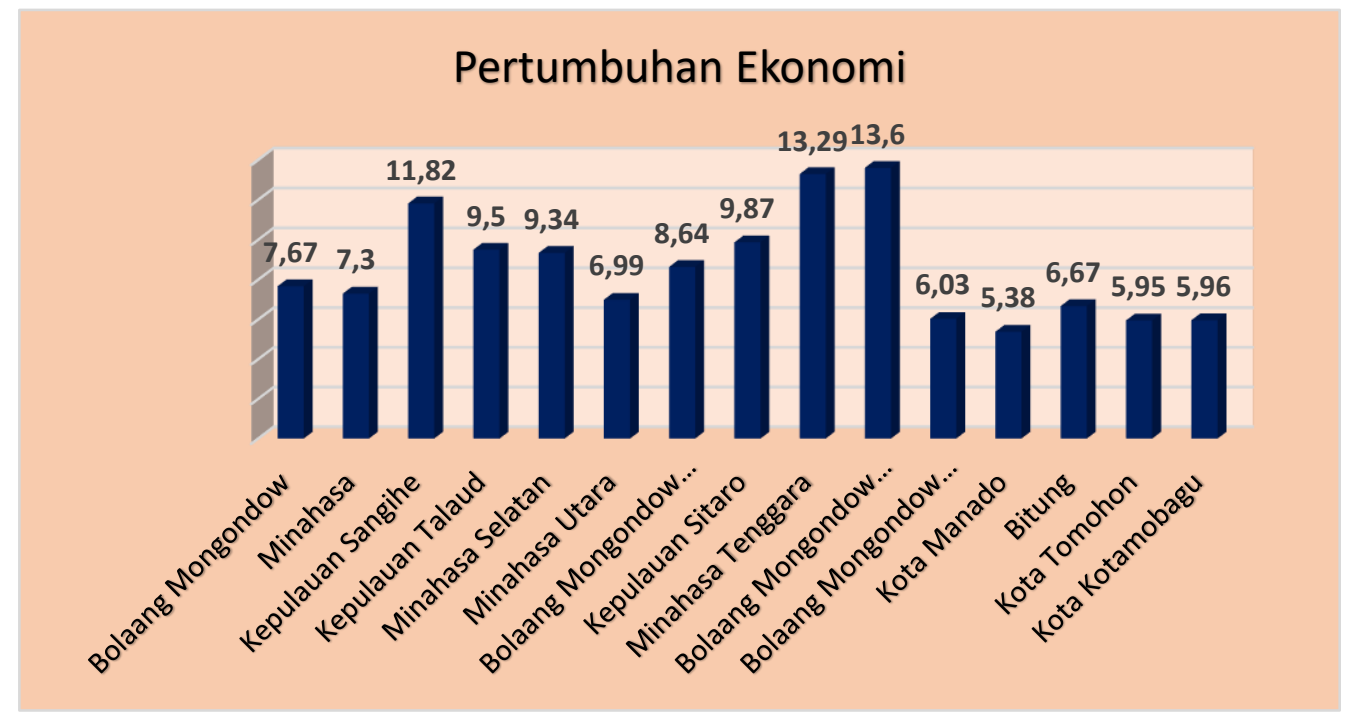

Sumber Data: BPS Sulut

Berdasarkan data yang ada tingkat kemiskinan di Provinsi Sulawesi Utara tahun 2018 untuk Kabupaten Kepulauan Sangihe berada di posisi ketiga dengan tingkat kemiskinan tertinggi yaitu sebesar 11,82 persen sedangkan Kabupaten Kepulauan Sitaro berada di posisi keempat tertinggi yakni 9,87 persen. Tingkat kemiskinan yang ada di Provinsi Sulawesi Utara khususnya Kepulauan Sangihe dan Sitaro diharapkan pemerintah dapat memberikan perhatian lebih dalam pengentasan kemiskinan.

\section{Pertumbuhan Ekonomi}

Pertumbuhan ekonomi suatu negara sebagai peningkatan kemampuan suatu negara untuk menyediakan barang-barang ekonomi bagi penduduknya, kenaikan pada kemampuan ini disebabkan oleh adanya kemajuan teknologi, kelembagaan serta penyesuaian ideologi yang dibutuhkannya. (Kuznet, S. 
dalam Todaro \& Smith, 2012). Ketiga komponen pokok dari definisi ini sangatlah penting maknanya bagi suatu perekonomian (Arsyad, 2010) yaitu.

1) Kenaikan output nasional secara terus menerus merupakan perwujudan dari pertumbuhan ekonomi dan pertumbuhan kemampuan suatu perekonomian dalam menyediakan berbagai berbagai macam barang ekonomi, dan juga tanda kematangan ekonomi.

2) Kemajuan teknologi merupakan syarat perlu (necessary condition) bagi pertumbuhan ekonomi yang berkesinambungan, namun bukan syarat cukup (sufficient condition) dalam merealisasikan potensi pertumbuhan yang terkandung dalam teknologi baru

3) Penyesuaian kelembagaan, sikap dan ideologi harus segera dilakukan. Adanya inovasi teknologi tanpa adanya inovasi sosial ibarat sebuah bola lampu tanpa aliran listrik. Potensi ada namun tanpa input yang melengkapi, tidak akan berarti apa-apa.

Di negara-negara maju, ada beberapa tekanan untuk menggeser orientasi pada pertumbuhan ekonomi menuju ke upaya-upaya yang lebih memperhatikan kualitas hidup (quality of life). Sementara itu, Negara sedang berkembang (NSB) yang menjadi perhatian utama adalah masalah pertumbuhan versus distribusi pendapatan. Banyak orang merasakan bahwa pertumbuhan ekonomi yang tinggi telah gagal untuk menghilangkan atau bahkan mengurangi luasnya kemiskinan absolute di NSB karena tingkat penggangguran dan pengangguran semu meningkat di daerah pedesaan dan perkotaan. Proses penetesan ke bawah (trickle down effect) dari manfaat pertumbuhan ekonomi bagi orang miskin tidak terjadi (Arsyad, 2010).

\section{Faktor-Faktor yang Mempengaruhi Pertumbuhan Ekonomi}

Adapun faktor-faktor yang mempengaruhi pertumbuhan ekonomi antara lain se bagai berikut:

1. Faktor Sumber Daya Manusia

Sama halnya dengan proses pembangunan, pertumbuhan ekonomi juga dipengaruhi oleh SDM. Sumber daya manusia merupakan faktor terpenting dalam proses pembangunan, cepat lambatnya proses pembangunan tergantung kepada sejauhmana sumber daya manusianya selaku subjek pembangunan memiliki kompetensi yang memadai untuk melaksanakan proses pembangunan.

2. Faktor Sumber Daya Alam

Sebagian besar negara berkembang bertumpu kepada sumber daya alam dalam melaksanakan proses pembangunannya. Namun demikian, sumber daya alam saja tidak menjamin keberhasilan proses pembanguan ekonomi, apabila tidak didukung oleh kemampaun sumber daya manusianya dalam mengelola sumber daya alam yang tersedia. Sumber daya alam yang dimaksud dinataranya kesuburan tanah, kekayaan mineral, tambang, kekayaan hasil hutan dan kekayaan laut.

3. Faktor Ilmu Pengetahuan dan Teknologi

Perkembangan ilmu pengetahuan dan teknologi yang semakin pesat mendorong adanya percepatan proses pembangunan, pergantian pola kerja yang semula menggunakan tangan manusia digantikan oleh mesin-mesin canggih berdampak kepada aspek efisiensi, kualitas dan kuantitas serangkaian aktivitas pembangunan ekonomi yang dilakukan dan pada akhirnya berakibat pada percepatan laju pertumbuhan perekonomian.

4. Faktor Budaya

Faktor budaya memberikan dampak tersendiri terhadap pembangunan ekonomi yang dilakukan, faktor ini dapat berfungsi sebagai pembangkit atau pendorong proses pembangunan tetapi dapat juga menjadi penghambat pembangunan. Budaya yang dapat mendorong pembangunan diantaranya sikap kerja keras dan kerja cerdas, jujur, ulet dan sebagainya. Adapun budaya yang dapat menghambat proses pembangunan diantaranya sikap anarkis, egois, boros, KKN, dan sebagainya. 
5. Sumber Daya Modal

Sumber daya modal dibutuhkan manusia untuk mengolah SDA dan meningkatkan kualitas IPTEK. Sumber daya modal berupa barang-barang modal sangat penting bagi perkembangan dan kelancaran pembangunan ekonomi karena barang-barang modal juga dapat meningkatkan produktivitas.

\section{Tenga Kerja}

Tenaga kerja memiliki beberapa definisi, menurut UU No 13 Tahun 2003 tentang ketenagakerjaan, tenaga kerja adalah setiap orang yang mampu melakukan pekerjaan guna menghasilkan barang dan/jasa baik untuk memenuhi kebutuhan sendiri maupun untuk masyarakat. Pada UU No. 25 tahun 1997 mendefinisikan tenaga kerja adalah penduduk usia 15 tahun atau lebih, sedangkan pada undang-undang terbaru tentangketenagakerjaan yaitu UU No. 13 tahun 2013 tidak memberikan batasan umur dalam definisi tenaga kerja, namun pada undang-undang tersebut melarang mempekerjakan anak -anak. Anak-anak menurut UU No. 25 tahun 1997 tentang ketenagakerjaan adalah orang laki-laki atau wanita yang berumur kurang dari 15 tahun. Tenaga kerja mencakup penduduk yang sudah atau sedang bekerja, yang sedang mencari pekerjaan, dan yang melakukan kegiatan lain seperti bersekolah dan mengurus rumah tangga (Simanjuntak, 1985).

Tenaga kerja atau manpower terdiri dari angkata kerja dan bukan angkatan kerja. Angkatan kerja atau labor force adalah bagian tenaga kerja yang ingin dan yang benar-benar menghasilkan barang dan jasa. Angkatan kerja terdiri dari golongan yang bekerja dan golongan yangmenganggur dan mencari pekerjaan. Kelompok bukan angkatan kerja terdiri dari golongan yang bersekolah, golongan yang mengurus rumah tangga, dan golongan lain -lain atau penerima pendapatan.Ketiga golongan dalam kelompok bukan angkatan kerja sewaktu -waktu dapat menawarkan jasanya untuk bekerja. Oleh sebab itu, kelompok ini sering dinamakan potensial labor force (Simanjuntak, 1985).

Menurut Sumarsono (2009) permintaan tenaga kerja dipengaruhi oleh beberapa faktor, yaitu:

1. Perubahan tingkat upah.

Perubahan tingkat upah dapat mempengaruhi tinggi rendahnya biaya produksi suatu perusahaan, jika diasumsikan bahwa tingkat upah naik, maka dapat terjadi hal berikut:

a. Naiknya tingkat upah dapat meningkatkan biaya produksi perusahaan yang selanjutnya dapat meningkatkan harga per unit barang yang diproduksi. Kenaikan harga barang tersebut dapat direspon oleh konsumen dengan mengurangi konsumsi atau bahkan tidak membeli barang tersebut kembali. Akibatnya banyak produksi yang tidak terjual, produsen terpaksa harus menurunkan jumlah produksinya. Turunnya jumlah produksi mengakibatkan berkurangnya tenaga kerja yang dibutuhkan. Penurunan jumlah tenaga kerja yang dibutuhkan karena turunnya skala produksi disebut dengan efek skala produksi (scale effect).

b. Jika upah naik (dengan asumsi harga hari barang modal lainnya tidak berubah), maka pengusaha ada yang lebih suka menggunakan teknologi padat modal untuk proses produksinya dan menggantikan kebutuhan terhadap tenaga kerja dengan kebuthan terhadap barang-barang modal seperti mesin dan lainnya. Penurunan jumlah tenaga kerja yang dibutuhkan karena adanya penggantian atau penambahan penggunaan mesin-mesin disebut dengan subtitusi tenaga kerja (substitution effect).

2. Faktor lain-lain.

a. Naik turunnya permintaan pasar terhadap hasil produksi dari perusahaan yang bersangkutan. Apabila permintaan hasil produksi meningkat maka produsen dapat menambah kapasita produksinya dengan menambah penggunaan tenaga kerjanya. 
b. Apabila harga barang-barang modalturun, maka biaya produksiturun dan tentunya mengakibatkanharga jual per unit barangturun.Pada keadaan ini produsen meningkatkan produksi barangnya karena permintaan bertambah banyak. Peningkatan permintaan tenaga kerja juga bertambah banyak seiring dengan peningkatan kegiatan perusahaan. Keadaa ini menyebabkan bergesernya kurva permintaan tenaga kerja kearah kanan dikarenakan pengaruh skala produksi (scale effect). Efek selanjutnya yang terjadi bila harga barang-barang modal turun adalah efek subtitusi. Keadaan ini terjadi karena produsen cenderung untuk menambah jumlah barang modal (mesin) sehingga terjadi capital intensif dalam proses produksi. Jadi secara relatif penggunaan tenaga kerjanya berkurang.

\section{Konsep teori Kemiskinan}

Secara Umum Definisi mengenai kemiskinan dibentuk berdasarkan identifikasi dan pengukuran terhadap sekelompok masyarakat/golongan yang selanjutnya disebut miskin (Nugroho, 1995). Pada umumnya, setiap negara termasuk Indonesia memiliki sendiri definisi seseorang atau suatu masyarakat dikategorikan miskin. Hal ini dikarenakan kondisi yang disebut miskin bersifat relatif untuk setiap negara misalnya kondisi perekonomian, standar kesejahteraan, dan kondisi sosial. Setiap definisi ditentukan menurut kriteria atau ukuran-ukuran berdasarkan kondisi tertentu, yaitu pendapatan rata-rata, daya beli atau kemampuan konsumsi rata-rata, status kependidikan, dan kondisi kesehatan. Secara umum, kemiskinan diartikan sebagai kondisi ketidakmampuan pendapatan dalam mencukupi kebutuhan pokok sehingga kurang mampu untuk menjamin kelangsungan hidup (Suryawati, 2004). Kemampuan pendapatan untuk mencukupi kebutuhan pokok berdasarkan standar harga tertentu adalah rendah sehingga kurang menjamin terpenuhinya standar kualitas hidup pada umumnya. Berdasarkan pengertian ini, maka kemiskinan secara umum didefinisikan sebagai suatu kondisi ketidakmampuan pendapatan dalam memenuhi kebutuhan pokok dan kebutuhan lainnya yang dapat menjamin terpenuhinya standar kualitas hidup. Berdasarkan Undang-Undang No. 24 Tahun 2004, kemiskinan adalah kondisi sosial ekonomi seseorang atau sekelompok orang yang tidak terpenuhinya hak-hak dasarnya untuk mempertahankan dan mengembangkan kehidupan yang bermartabat.

Kebutuhan dasar yang menjadi hak seseorang atau sekelompok orang meliputi kebutuhan pangan, kesehatan, pendidikan, pekerjaan, perumahan, air bersih, pertanahan, sumber daya alam, lingkungan hidup, rasa aman dari perlakuan atau ancaman tindak kekerasan, dan hak untuk berpartisipasi dalam penyelenggaraan kehidupan sosial dan politik. Laporan Bidang Kesejahteraan Rakyat yang dikeluarkan oleh Kementrian Bidang Kesejahteraan (Kesra) tahun 2004 menerangkan pula bahwa kondisi yang disebut miskin ini juga berlaku pada mereka yang bekerja akan tetapi pendapatannya tidak mencukupi untuk memenuhi kebutuhan pokok/dasar.

Definisi kemiskinan kemudian dikaji kembali dan diperluas berdasarkan permasalahanpermasalahan kemiskinan dan faktor-faktor yang selanjutnya menyebabkan menjadi miskin. Definisi kemiskinan yang dikemukakan oleh Chambers adalah definisi yang saat ini mendapatkan perhatian dalam setiap program pengentasan kemiskinan di berbagai negara-negara berkembang dan dunia ketiga. Pandangan yang dikemukakan dalam definisi kemiskinan dari Chambers menerangkan bahwa kemiskinan adalah suatu kesatuan konsep (integrated concept) yang memiliki lima dimensi, yaitu:

1. Kemiskinan (Proper)

Permasalahan kemiskinan seperti halnya pada pandangan semula adalah kondisi ketidakmampuan pendapatan untuk mencukupi kebutuhan-kebutuhan pokok. Konsep atau pandangan ini berlaku tidak hanya pada kelompok yang tidak memiliki pendapatan, akan tetapi dapat berlaku pula pada kelompok yang telah memiliki pendapatan. 
2. Ketidakberdayaan (Powerless)

Pada umumnya, rendahnya kemampuan pendapatan akan berdampak pada kekuatan sosial (social power) dari seseorang atau sekelompok orang terutama dalam memperoleh keadilan ataupun persamaan hak untuk mendapatkan penghidupan yang layak bagi kemanusiaan.

3. Kerentanan menghadapi situasi darurat (State of emergency)

Seseorang atau sekelompok orang yang disebut miskin tidak memiliki atau kemampuan untuk menghadapi situasi yang tidak terduga di mana situasi ini membutuhkan alokasi pendapatan untuk menyelesaikannya. Misalnya, situasi rentan berupa bencana alam, kondisi kesehatan yang membutuhkan biaya pengobatan yang relatif mahal, dan situasi-situasi darurat lainnya yang membutuhkan kemampuan pendapatan yang dapat mencukupinya. Kondisi dalam kemiskinan dianggap tidak mampu untuk menghadapi situasi ini.

4. Ketergantungan (dependency)

Keterbatasan kemampuan pendapatan ataupun kekuatan sosial dari seseorang atau sekelompok orang yang disebut miskin tadi menyebabkan tingkat ketergantungan terhadap pihak lain adalah sangat tinggi. Mereka tidak memiliki kemampuan atau kekuatan untuk menciptakan solusi atau penyelesaian masalah terutama yang berkaitan dengan penciptaan pendapatan baru. Bantuan pihak lain sangat diperlukan untuk mengatasi persoalan-persoalan terutama yang berkaitan dengan kebutuhan akansumber pendapatan.

5. Keterasingan (Isolation)

Dimensi keterasingan seperti yang dimaksudkan oleh Chambers adalah faktor lokasi yang menyebabkan seseorang atau sekelompok orang menjadi miskin. Pada umumnya, masyarakat yang disebut miskin ini berada pada daerah yang jauh dari pusat-pusat pertumbuhan ekonomi. Hal ini dikarenakan sebagian besar fasilitas kesejahteraan lebih banyak terkonsentrasi di pusat-pusat pertumbuhan ekonomi seperti di perkotaan atau kota-kota besar. Masyarakat yang tinggal di daerah terpencil atau sulit dijangkau oleh fasilitas-fasilitas kesejahteraan relatif memiliki taraf hidup yang rendah sehingga kondisi ini menjadi penyebab adanya kemiskinan.

\section{Metode Penelitian}

\section{Data dan Sumber Data}

Jenis data yang digunakan dalam penelitian ini adalah data sekunder, yang berupa data determinan pertumbuhan ekonomi penyerapan tenaga kerja dan kemiskinan. Objek penelitian ini adalah: Kabupaten Kepulauan Talaud.

\section{Metode Analisis}

Metode analisis yang digunakan dalam penelitian ini yaitu analisis jalur. Analisis ini digunakan untuk mengetahui pengaruh variabel independen terhadap variabel dependen melalui variabel intervening. Variabel dependen merupakan variabel yang dipengaruh oleh variabel independen. Variabel independen merupakan variabel yang mempengaruhi variabel lain. Sedangkan intervening adalah variabel yang mempengaruhi hubungan antara variabel independen dan variabel dependen menjadi hubungan yang tidak langsung. 


\section{Analisis Path}

Pada penelitian ini, peneliti menggunakan analisis jalur (Path Analysis). Menurut Rutherford (1993) Analisis jalur ialah suatu teknik untuk menganalisis hubungan sebab akibat yang terjadi pada regres berganda jika variabel bebasnya mempengaruhi variabel tergantung tidak hanya secara langsung tetapi juga secara tidak langsung, Sedangkan menurut Webley (1997) mengatakan analisis jalur merupakan pengembangan langsung bentuk regresi berganda dengan tujuan untuk memberikan estimasi tingkat kepentingan (magnitude) dan signifikansi (significance) hubungan sebab akibat hipotetikal dalam seperangkat variabel (Sugiono, 2012). Dari beberapa definisi diatas, dapat disimpulkan bahwa sebenarnya analisis jalur merupakan kepanjangan dari regresi berganda.

Regresi dikenakan pada masing-masing variabel dalam suatu model sebagai variabel tergantung (pemberi respon) sedangan yang lain sebagai penyebab. Pembobotan regresi diprediksikan dalam suatu model yang dibandingkan dengan matriks korelasi yang diobservasi untuk semua variabel dan dilakukan juga penghitungan uji keselarasan statistik.

\section{Manfaat Analisis Jalur}

Ada beberapa manfaat dari model path analysis, antara lain:

1. untuk penjelasan terhadap fenomena yang dipelajari atau permasalahan yang diteliti;

2. untuk prediksi nilai variable terikat (Y) berdasarkan nilai variable bebas (X) dan prediksi ini bersifat kualitatif;

3. factor determinan yaitu penentuan variable bebas $(\mathrm{X})$ mana yang berpengaruh dominan terhadap variable terikat (Y), juga dapat digunakan untuk menelusuri (jalur-jalur)pengaruh variable babas $(\mathrm{X})$ terhadap variable terikat $(\mathrm{Y})$.

\section{Diagram Jalur dan Persamaan Analisis}

Sesuai dengan judul yang diambil maka berikut ini akan tampilkan model analisi dua jalur dalam gambar 1 sebagai berikut:

\section{Gambar 1. Struktur Model Penelitian}

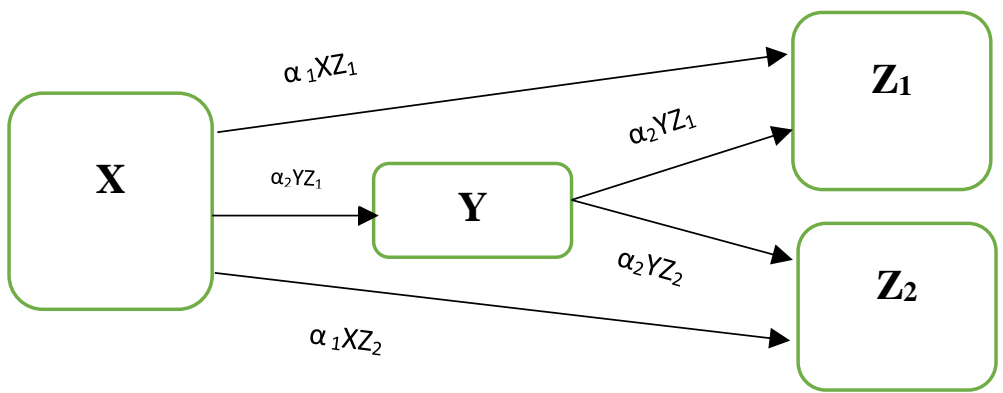

Keterangan:

$\mathrm{X}=$ Belanja Langsung

$\mathrm{Y}=$ Pertumbuhan Ekonomi

$\mathrm{Z}_{1}=$ Penyerapan Tenaga Kerja

$\mathrm{Z}_{2}=$ Kemiskinan

$\alpha=$ Konstanta/ Intercept

$\beta=$ Koefisien Regresi

$\mathrm{e} \quad=$ Standar Eror 
Terlihat pada gambar 1 bahwa setiap variabel memiliki hubungan antara lain, baik adanya hubungan secara langsung maupun secara tidak langsung dan memiliki variabel endogen dan eksogen. Pengaruh tidak langsung suatu variabel eksogen terhadap variabel endogen adalah melalui variabel lain yang disebut variabel antara (intervening variable).

\section{Persamaan Substruktur 1}

Dalam analisis ini persamaan model substruktur 1 dapat ditulis dengan persamaan matematis berikut

$\mathbf{Y}=\mathbf{a}_{1} \mathbf{X}+\mathbf{E}_{1}$

Dari persamaan tersebut jelas dilihat bahwa Y merupakan variabel dependen, sedangkan X adalah variabel independen. Pada persamaan substruktur 1 ini akan dijawab pengaruh variabel $\mathrm{X}$ terhadap $\mathrm{Y}$.

\section{Persamaan Substruktur 2}

Dalam analisis ini persamaan model substruktur 2 dapat ditulis dengan persamaan matematis berikut

$$
\mathbf{Z}_{1}=\mathbf{a}_{1} \mathbf{X}+\mathbf{a}_{2} \mathbf{Y}+\mathbf{E}_{2}
$$

Dari persamaan tersebut jelas dilihat bahwa $\mathrm{Z}_{1}$ merupakan variabel dependen, sedangkan $\mathrm{X}$ dan $\mathrm{Y}$ adalah variabel independen. Pada persamaan substruktur 2 ini akan dijawab pengaruh variabel $\mathrm{X}_{1}, \mathrm{Y}$ terhadap $\mathrm{Z}_{1}$.

\section{Persamaan Substruktur 3}

Dalam analisis ini persamaan model substruktur 2 dapat ditulis dengan persamaan matematis berikut

$\mathbf{Z}_{2}=\mathbf{a}_{1} \mathbf{X}+\mathbf{a}_{2} \mathbf{Y}+\mathbf{E}_{3}$

Dari persamaan tersebut jelas dilihat bahwa $\mathrm{Z}_{2}$ merupakan variabel dependen, sedangkan $\mathrm{X}$ dan $\mathrm{Y}$ adalah variabel independen. Pada persamaan substruktur 2 ini akan dijawab pengaruh variabel $\mathrm{X}$ dan $\mathrm{Y}$ terhadap $\mathrm{Z}_{2}$.

\section{Hasil Penelitian dan Pembahasan}

\section{Hasil Estimasi}

Berikut adalah hasil estimasi Determinan Pertumbuhan Ekonomi dan Dampaknya terhadap Penyerapan Tenaga Kerja Serta Kemiskinan di Kabupaten Kepulauan Sangihe

\section{Persamaan Substruktur 1}

Berikut ini merupakan hasil olah data dengan menggunakan Eviews 08 untuk mengetahui pengaruh Belanja Langsung terhadap Pertumbuhan Ekonomi. Hasil regresi tersebut dapat dilihat pada tabel 1 berikut:

$\mathbf{Y}=\mathbf{a} 1 \mathbf{X}+\mathbf{E}_{1}$

$Y=0.439349 X+0.956$ 
Tabel 1. Hasil Regresi Persamaan Substruktur 1 Belanja Langsung (x) terhadap Pertumbuhan Ekonomi (Y)

\begin{tabular}{|c|c|c|c|}
\hline Variabel & Coefficient & t- statistic & Probabilitas \\
\hline $\mathbf{X}$ & 0.439349 & 0.646983 & 0,5338 \\
\hline $\mathbf{R}^{\mathbf{2}}=0,044$ & \multicolumn{3}{|r|}{ F- statistic $=0.41$} \\
\hline
\end{tabular}

Sumber: Hasil Olah Data Eviews 08

Belanja Langsung mempunyai nilai koefisien sebesar 0.439349 yang berarti bahwa belanja langsung memiliki pengaruh positif terhadap pertumbuhan ekonomi. Artinya apabila belanja langsung meningkat maka pertumbuhan ekonomi akan meningkat pula cateris paribus. Pengaruh tersebut sesuai denga teori akan tetapi hasil yang didapat tidak signifikan secara statistik. Ketika terjadi kenaikan belanja langsung tidak akan memberikan pengaruh yang signifikan terhadap pertumbuhan ekonomi. Diduga bahwa belanja langsung yang digunakan tidak menyentuh langsung untuk mendorong pertumbuhan ekonomi secara langsung.

\section{Persamaan Substruktur 11}

Berikut ini merupakan hasil olah data dengan menggunakan Eviews 08 untuk mengetahui pengaruh Belanja Langsung dan Pertumbuhan Ekonomi terhadap Penyerapan Tenaga Kerja. Hasil regresi tersebut dapat dilihat pada tabel 2 berikut:

$$
\begin{aligned}
& Z_{1}=a_{1} X+a_{2} Y+E_{2} \\
& Z_{1}=0.096582 X+0.038197 Y+0.237
\end{aligned}
$$

\section{Tabel 2}

Hasil Regresi Persamaan Substruktur 11 Belanja Langsung (x) dan Pertumbuhan Ekonomi (Y) terhadap Penyerapan Tenaga Kerja $\mathrm{Z}_{1}$

\begin{tabular}{|c|c|c|c|}
\hline Variabel & Coefficient & t- statistic & Probabilitas \\
\hline $\mathbf{X}$ & 0.096582 & 4.305384 & 0.0026 \\
\hline $\mathbf{Y}$ & -0.038197 & -3.548562 & 0.0075 \\
\hline $\mathbf{R}^{\mathbf{2}}=0,763$ & \multicolumn{3}{|r}{ F- statistic $=12.9$} \\
\hline
\end{tabular}

Sumber: Hasil Olah Data Eviews 08

Belanja Langsung mempunyai nilai koefisien sebesar 0.096582 yang berarti bahwa belanja langsung memiliki pengaruh positif terhadap penyerapan tenaga kerja. Artinya apabila belanja langsung meningkat maka penyerapan tenaga kerja akan meningkat pula cateris paribus. Pengaruh tersebut sesuai dengan teori dan signifikan secara statistik. Artinya ketika terjadi kenaikan belanja langsung akan memberikan pengaruh yang signifikan terhadap kenaikan penyerapan tenaga kerja. Kebijakan yang digunakan dalam menggunakan belanja langsung sudah mampu menyentuh secara tepat kepada sekor-sektor yang membutukan tenaga kerja sehingga mampu menyerap tenaga kerja.

Pertumbuhan ekonomi mempunyai nilai koefisien -0.038197 yang berarti bahwa pertumbuhan ekonomi memiliki pengaruh negatif dan signifikan secara statistik terhadap penyerapan tenaga kerja. Artinya ketika pertumbuhan ekonomi meningkat, maka akan mengakibatkan menurunnya penyerapan tenaga kerja cateris paribus. Hasil ini tidak sesuai dengan teori yang menyebutkan bahwa pertumbuhan ekonomi berpengaruh positif terhadap penyerapan tenaga kerja. Yang berarti ketika terjadi kenaikan 
pertumbuhan ekonomi maka akan meningkat pula penyerapan tenaga kerja. Dari hasil yang didapat diduga bahwa tidak tercatatnya penduduk yang bekerja pada sektor-sektor ekonomi.

Nilai F-statistik sebesar 12.9 sedangkan F-tabel 5.12, dengan demikian F-statistik lebih besar dari F-tabel yang berarti bahwa belanja langsung dan pertumbuhan ekonomi secara Bersama-sama berpengaruh signifikan terhadap penyerapan tenaga kerja. Nilai $\mathrm{R}^{2}$ yang diperoleh sebesar 0.763 . Artinya, variasi belanja langsung dan pertumbuhan ekonomi mempengaruhi penyerapan tenaga kerja sebesar 76,3\% sedangkan sisanya $23,7 \%$ dijelaskan oleh variabel-variabel lain yang tidak dimasukkan dalam model.

\section{Persamaan Substruktur 111}

Berikut ini merupakan hasil olah data dengan menggunakan Eviews 08, untuk mengetahui pengaruh Belanja Langsung dan Pertumbuhan Ekonomi terhadap Kemiskinan. Hasil regresi tersebut dapat dilihat pada tabel 2 berikut:

$$
\begin{aligned}
& Z_{2}=a_{1} X+a_{2} Y+E_{3} \\
& Z_{2}=-0.019274 X+0.028723 Y+0.628
\end{aligned}
$$

\section{Tabel 3}

Hasil Regresi Persamaan Substruktur 111 Belanja Langsung (x) dan Pertumbuhan Ekonomi (Y) terhadap

Kemiskinan $\mathrm{Z}_{2}$

\begin{tabular}{|c|c|c|c|}
\hline Variabel & Coefficient & t- statistic & Probabilitas \\
\hline $\mathbf{X}$ & -0.019274 & -0.696877 & 0.5056 \\
\hline $\mathbf{Y}$ & 0.028723 & 2.164385 & 0.0624 \\
\hline $\mathbf{R}^{\mathbf{2}}=\mathbf{0 . 3 7 2}$ & \multicolumn{3}{|r}{ F- statistic $=2.37$} \\
\hline
\end{tabular}

Sumber: Hasil Olah Data Eviews 08

Belanja Langsung mempunyai nilai koefisien sebesar -0.019274 yang berarti bahwa belanja langsung memiliki pengaruh yang negatif terhadap kemiskinan. Artinya, apabila belanja langsung meningkat maka kemiskinan akan turun begitu sebaliknya cateris paribus. Hasil ini sesuai dengan teori yang menyatakan adanya hubungan negatif antara belanja langsung dengan kemiskinan. Akan tetapi, hasil ini tidak signifikan secara statistik. Belanja langsung yang di lakukan oleh pemerintah sudah mampu menurunkan kemiskinan walaupun penurunannya tidak signifikan. Belanja langsung yang digunakan belum maksimal untuk menekan angka kemiskinan secara signifikan.

Pertumbuhan ekonomi mempunyai nilai koefisien sebesar 0.028723 yang berarti bahwa pertumbuhan ekonomi memiliki pengaruh positif dan signifikan terhadap kemiskinan. Artinya, ketika terjadi peningkatan pertumbuhan ekonomi, kemiskinan akan meingkat begitu sebaliknya cateris paribus. Hasil ini tidak sesuai dengan teori yang menyatakan bahwa pertumbuhan ekonomi berpengaruh negative terhadap kemiskinan. Menurut tambunan (2001) menyatakan bahwa pertumbuhan ekonomi tanpa dibarengi dengan penambahan kesempatan kerja akan mengakibatkan ketimpangan dalam pembangian dari penambahan pendapatan tersebut (cateris paribus), yang selanjutnya akan menciptakan suatu kondisi pertumbuhan ekonomi dengan peningkatan kemiskinan.

Nilai F-statistik sebesar 2.37 sedangkan F-tabel 5.12, dengan demikian F-statistik lebih kecil dari Ftabel yang berarti bahwa belanja langsung dan pertumbuhan ekonomi secara bersama-sama tidak berpengaruh signifikan terhadap kemiskinan. Nilai $\mathrm{R}^{2}$ yang diperoleh sebesar 0.372 Artinya, variasi belanja langsung dan pertumbuhan ekonomi mempengaruhi kemiskinan sebesar 37,2\% sedangkan sisanya $62.8 \%$ dijelaskan oleh variabel-variabel lain yang tidak dimasukkan dalam model. 


\section{Hasil Estimasi}

Berikut adalah hasil estimasi Determinan Pertumbuhan Ekonomi dan Dampaknya terhadap Penyerapan Tenaga Kerja Serta Kemiskinan di Kabupaten Kepulauan Siau Tagulandang Biaro

\section{Persamaan Substruktur 1}

Berikut ini merupakan hasil olah data dengan menggunakan Eviews 08 untuk mengetahui pengaruh Belanja Langsung terhadap Pertumbuhan Ekonomi. Hasil regresi tersebut dapat dilihat pada tabel 1 berikut:

$$
\begin{aligned}
& Y=a_{1} X+E_{1} \\
& Y=-1.631505 X+0.568
\end{aligned}
$$

Tabel 4

Hasil Regresi Persamaan Substruktur 1 Belanja Langsung (x) terhadap Pertumbuhan Ekonomi (Y)

\begin{tabular}{|c|c|c|c|}
\hline Variabel & Coefficient & t- statistic & Probabilitas \\
\hline $\mathbf{X}$ & -1.631505 & -2.618283 & 0.0279 \\
\hline $\mathbf{R}^{\mathbf{2}}=0.432$ & \multicolumn{3}{|c}{ F- statistic $=6.85$} \\
\hline
\end{tabular}

Sumber: Hasil Olah Data Eviews 08

Belanja Langsung mempunyai nilai koefisien sebesar -1.631505 yang berarti bahwa belanja langsung memiliki pengaruh negatif dan signifikan secara statistic terhadap pertumbuhan ekonomi. Artinya apabila belanja langsung meningkat maka pertumbuhan ekonomi akan turun begitu sebaliknya cateris paribus. Hasil yang didapat tidak sesuai dengan teori yang menyatakan bahwa belanja langsung berpengaruh positif terhadap pertumbuhan ekonomi. Yang artinya bahwa belanja langsung yang digunakan tidak untuk mendorong peningkatan pertumbuhan ekonomi secara langsung. Sehingga walaupun adanya kenaikan dari sisi anggaran belanja langsung tidak bisa mendorong peningkatan pertumbuhan ekonomi.

\section{Persamaan Substruktur 11}

Berikut ini merupakan hasil olah data dengan menggunakan Eviews 08 untuk mengetahui pengaruh Belanja Langsung dan Pertumbuhan Ekonomi terhadap Penyerapan Tenaga Kerja. Hasil regresi tersebut dapat dilihat pada tabel 2 berikut:

$$
\begin{aligned}
& Z_{1}=a_{1} X+a_{2} Y+E_{2} \\
& Z_{1}=0.024483 X-0.024511 Y+0.691
\end{aligned}
$$

Tabel 5

Hasil Regresi Persamaan Substruktur 11

Belanja Langsung (x) dan Pertumbuhan Ekonomi (Y) terhadap Penyerapan Tenaga Kerja $\mathrm{Z}_{1}$

\begin{tabular}{|c|c|c|c|}
\hline Variabel & Coefficient & t- statistic & Probabilitas \\
\hline $\mathbf{X}$ & 0.024483 & 0.441964 & 0.6702 \\
\hline $\mathbf{Y}$ & -0.024511 & -1.097854 & 0.3042 \\
\hline $\mathbf{R}^{2}=0.309$ & \multicolumn{3}{r}{ F- statistic $=1.79$} \\
\hline
\end{tabular}

Sumber: Hasil Olah Data Eviews 08 
Belanja Langsung mempunyai nilai koefisien sebesar 0.024483 yang berarti bahwa belanja langsung memiliki pengaruh positif terhadap penyerapan tenaga kerja. Artinya apabila belanja langsung meningkat maka penyerapan tenaga kerja akan meningkat pula, begitu sebaliknya cateris paribus. Hasil tersebut sesuai dengan teori akan tetapi tidak signifikan secara statiktik. Dimana ketika meningkatnya anggaran belanja langsung yang digunakan tepat sasaran untuk sektor-sektor ekonomi yang produktif dan ungguk maka akan membutuhkan lebih banyak lagi tenaga kerja yang dibutuhkan sehingga akan terjadi peningkatan penyerapan tenaga kerja, walaupun secara statistik penyerapan tenaga kerja tidak signifikan.

Pertumbuhan ekonomi mempunyai nilai koefisien - 0.024511 yang berarti bahwa pertumbuhan ekonomi memiliki pengaruh negatif terhadap penyerapan tenaga kerja. Artinya ketika pertumbuhan ekonomi meningkat, maka akan mengakibatkan menurunnya penyerapan tenaga kerja cateris paribus. Hasil ini tidak sesuai dengan teori yang menyebutkan bahwa pertumbuhan ekonomi berpengaruh positif terhadap penyerapan tenaga kerja. Yang berarti ketika terjadi kenaikan pertumbuhan ekonomi maka akan meningkat pula penyerapan tenaga kerja walaupun tidak signifikan secara statistik. Dari hasil yang didapat diduga bahwa tidak tercatatnya penduduk yang bekerja pada sektor-sektor ekonomi.

Nilai F-statistik sebesar 1.79 sedangkan F-tabel 5.12, dengan demikian F-statistik lebih kecil dari Ftabel yang berarti bahwa belanja langsung dan pertumbuhan ekonomi secara bersama-sama tidak berpengaruh signifikan terhadap penyerapan tenaga kerja. Nilai $\mathrm{R}^{2}$ yang diperoleh sebesar 0.309 . Artinya, variasi belanja langsung dan pertumbuhan ekonomi mempengaruhi penyerapan tenaga kerja sebesar 30,9\% sedangkan sisanya 69,1\% dijelaskan oleh variabel-variabel lain yang tidak dimasukkan dalam model.

\section{Persamaan Substruktur 111}

Berikut ini merupakan hasil olah data dengan menggunakan Eviews 08 untuk mengetahui pengaruh Belanja Langsung dan Pertumbuhan Ekonomi terhadap Kemiskinan. Hasil regresi tersebut dapat dilihat pada tabel 2 berikut:

$$
\begin{aligned}
& Z_{2}=a_{1} X+a_{2} Y+E_{3} \\
& Z_{2}=-0.109496 X-0.008969 Y+0.715
\end{aligned}
$$

\section{Tabel 6}

Hasil Regresi Persamaan Substruktur 111 Belanja Langsung (x) dan Pertumbuhan Ekonomi (Y) terhadap Kemiskinan $\mathbf{Z}_{2}$

\begin{tabular}{|c|c|c|c|}
\hline Variabel & Coefficient & t- statistic & Probabilitas \\
\hline $\mathbf{X}$ & -0.109496 & -1.530693 & 0.1644 \\
\hline $\mathbf{Y}$ & -0.008969 & -0.311088 & 0.7637 \\
\hline $\mathbf{R}^{2}=0.285$ & \multicolumn{3}{|c|}{ F- statistic $=1.597$} \\
\hline
\end{tabular}

Sumber: Hasil Olah Data Eviews 08

Belanja Langsung mempunyai nilai koefisien sebesar -0.109496 yang berarti bahwa belanja langsung memiliki pengaruh yang negatif terhadap kemiskinan. Artinya, apabila belanja langsung meningkat maka kemiskinan akan turun begitu sebaliknya cateris paribus. Hasil ini sesuai dengan teori yang menyatakan adanya hubungan negatif antara belanja langsung dengan kemiskinan. Akan tetapi, hasil ini tidak signifikan secara statistik. Belanja langsung yang di lakukan oleh pemerintah sudah mampu menurunkan kemiskinan walaupun penurunannya tidak signifikan. Belanja langsung yang digunakan belum maksimal untuk menekan angka kemiskinan secara signifikan.

Pertumbuhan ekonomi mempunyai nilai koefisien sebesar -0.008969 yang berarti bahwa pertumbuhan ekonomi memiliki pengaruh negatif terhadap kemiskinan. Artinya, ketika terjadi peningkatan 
pertumbuhan ekonomi maka kemiskinan akan turun begitu sebaliknya cateris paribus. hasil ini sesuai dengan teori yang menyatakan bahwa pertumbuhan ekonomi berpengaruh negatif terhadap kemiskinan. Artinya meningkatnya pertumbuhan ekonomi maka akan menurunkan angka kemiskinan walaupun dari hasil yang didapat penurunan kemiskinan belum signifikan secara statistik. Pertumbuhan ekonomi memang tidak cukup untuk mengentaskan kemiskinan tetapi biasanya pertumbuhan ekonomi merupakan sesuatu yang dibutuhkan, walaupun begitu pertumbuhan ekonomi yang bagus pun menjadi tidak akan berarti bagi masyarakat miskin jika tidak diiringi dengan pemerataan pendapatan (Wongdesmiwati 2009)

Nilai F-statistik sebesar 1.597 sedangkan F-tabel 5.12, dengan demikian F-statistik lebih kecil dari F-tabel yang berarti bahwa belanja langsung dan pertumbuhan ekonomi secara bersama-sama tidak berpengaruh signifikan terhadap kemiskinan. Nilai $\mathrm{R}^{2}$ yang diperoleh sebesar 0.285 Artinya, variasi belanja langsung dan pertumbuhan ekonomi mempengaruhi penyerapan tenaga kerja sebesar $28.5 \%$ sedangkan sisanya 71,5\% dijelaskan oleh variabel-variabel lain yang tidak dimasukkan dalam model.

\section{Penutup}

\section{Kesimpulan}

1. Hasil penelitian di Kabupaten Kepulauan Sangihe menunjukan bahwa belanja langsung berpengaruh positif terhadap pertumbuhan ekonomi sedangkan di Kabupaten Kepulauan Siau Tagulandang Biaro belanja langsung berpengaruh negatif terhadap pertumbuhan ekonomi.

2. Hasil penelitian di Kabupaten Kepulauan sangihe menunjukan bahwa belanja langsung berpengaruh positif terhadap penyerapatan tenaga kerja dan pertumbuhan ekonomi berpengaruh negatif terhadap penyerapan tenaga kerja. Sedangkan di Kabupaten Kepulauan Siau Tagulandang Biaro belanja langsung berpengaruh positif terhadap penyerapan tenaga kerja dan pertumbuhan ekonomi berpengaruh negative terhadap penyerapan tenaga kerja.

3. Hasil penelitian di Kabupaten Kepulauan Sangihe menunjukan bahwa belanja langsung berpengaruh negatif terhadap kemiskinan dan pertumbuhan ekonomi berpengaruh positif terhadap kemiskinan. Sedangkan di Kabupaten Kepulauan Siau Tagulandang Biaro belanja langsung dan pertumbuhan ekonomi berpengaruh negatif terhadap kemiskinan.

\section{Saran}

Bagi pemerintah daerah sebaiknya lebih mengoptimalkan lagi anggaran belanja langsung untuk sektor-sektor potensial dan unggul demi mendorong pertumbuhan ekonomi daerah. Sehingga dengan meningkatkan pertumbuhan ekonomi pada sector-sektor yang potensial mampu menyerap tenaga kerja sehingga akan memperbaiki pendapatan masyarakat. Juga diharapkan pemerintah dalam membuat kebijakan-kebijakan agar langsung bisa menyentuh masyarakat miskin sehingga anggaran yang di keluarkan dapat berpengaruh signifikan dalam menekan angka kemiskinan di daerah.

\section{DAFTAR PUSTAKA}

Arsyad, L. 2010. Ekonomi Pembangunan. Yogyakarta: UPP STIM YKPN

Nugroho, H. 1995. “Kemiskinan, Ketimpangan dan Pemberdayaan, dalam Kemiskinan dan Kesenjangan di Indonesia”. Yogyakarta: Aditya Media.

Nasir, dkk. (2008), "Analisis Faktor - Faktor Yang Mempengaruhi Kemiskinan Rumah Tangga Di Kabupaten Purworejo" Jurnal Ekskutif. Vol. 5 No. 4. 
Rutherford, Robert D dan Minja Kim Choe. (1993). Statistical Model For Causal Analysis. New York: John Wiley \& Sons.Inc

Simanjuntak, P. 1985. Pengantar Ekonomi Sumber Daya Manusia, FE UI: Jakarta

Sumarsono, S. 2009. Ekonomi Sumber Daya Manusia Teori dan Kebijakan Publik. .Jogyakarta: Graha Ilmu.

Suryawati. 2004. Teori Ekonomi Mikro. UPP. AMP YKPN. Yogyakarta: Jarnasy.

Sugiono. 2012. Metode Penelitian Kuantitatif Kualitatif dan R\&D. Bandung: CV. Alfabeta

Sianturi, S. M T. 2011. Analisis adeterminan Jumlah Penduduk MiskinProvinsi Sumatera. Thesis. Pasca Sarjana Universitas Sumatera Utara.

Tambunan, T. 2001. Perekonomian Indonesia: Teori dan Temuanempiris.CetakanKedua.Jakarta.

Todaro. M.P., dan Smith. S.C. 2012. “Pembangunan Ekonomi”, Edisi Sebelas. Jakarta: Erlangga

Webley, P., dan Lea. S. 1997. Path Analysis. Exeter, UK: Depertment of Psychology, University of Exeter.

Wongdeswati. 2014. "Pertumbuhan Ekonomi dan Pengentasan Kemiskinan di Indonesia: Analisis Ekonometrika" 